\title{
News From JMRT
}

At the ALA Annual Conference in June, the Junior Members Round Table is sponsoring an exhibit booth which will feature "Rap Sessions" with spokesmen representing various causes and organizations. These "Rap Sessions" will enable people attending the convention and touring the exhibit area to meet with these representatives and talk with them.

Among the groups who will have spokesmen at the JMRT booth in Dallas are the Los Angeles County Public Library Project working with Chicanos, and the ALA Social Responsibilities of Libraries Round Table. There are still time slots open for other groups who wish to have spokesmen represented at our booth. Organizations represented at the booth do not have to be directly connected to library services. Last year at our booth, representatives from Women's Liberation had a very successful "Rap Session" with a group of interested conventioneers, and in the process collected over 3,000 signatures on a petition.

Any organization or group committed to a political, cultural, or social cause and who wants to have a spokesman at our booth should contact Jack Forman, JMRT Booth Chairman, Free Public Library of Woodbridge, 800 Rahway Ave., Woodbridge, N.J. 07095 as soon as possible.

As part of their convention activities JMRT will also sponsor the JMRT Dinner, June 21. The dinner will be held at the Country Dinner Playhouse, where you will dine from a lavish buffet and be entertained by Neil Simon's Broadway hit, "The Star-Spangled Girl," His romance-protest farce unravels a yarn about the haphazard adventures of two San Franciscans trying to put out a magazine of controversy with a Yankee-doodle doll who used to be an Olympic swimmer. After the play, more relaxation and dancing. Then, back to the hotels in the same air-conditioned comfort that brought you to the Playhouse. Send your $\$ 12.50$ now (made payable to "JMRT Dinner") to JMRT Dinner, Dallas Public Library, 1954 Commerce Street, Dallas, Texas 75201 . The price includes dinner, theater, dancing, transportation to and from the Playhouse (from downtown hatels only), and gratuities. There will be a cash bar.

- Being "Ad Hoc" until the next Georgia Library Association Conference has not kept the Georgia Library Association/Junior Members Round Table inactive. A Georgia Library Association Conference workshop, "Up The Organization," focused on ways of getting human development included in organizational objec- tives. At the Southeastern Library Association: a program on the Right To Read movement, a tour of underground Atlanta, and manning the Publishers of Peace booth. Plans for 1971 include a program on library education "co-produced" with Georgia Library Association/Library Education Division.

- Sunday afternoon, June 20, at 2:00 p.m., JMRT and the ALA Membership Committee will cosponsor an orientation program to introduce and orientate first-time, conference attendees to the sights and sounds of an ALA conference. The officers and Executive Board of the Association are currently planning to attend. For those attending their first conference, this program is a "must."

ACRL Membership

April 30, 1971

10,746

April 30, 1970

10,520

April 30, 1969

12,088

\section{Anglo-American Cataloging Rules}

North American Text, C. Sumner Spalding, general editor

Supplement of Additions and Changes Available in These Three Editions

410p Paper ISBN 0-8389-3119-7 (1970) $\$ 4.75$

$410 \mathrm{p}$ Cloth ISBN $0.8389 .3011-5 \quad(1970) \quad \$ 9.50$

12p Supplement for your 1967 edition

Paper ISBN 0-8389-5272-0 (1971)

$3-\$ 1.50 \quad 10-\$ 4.00 \quad 25-\$ 9.00 \quad 50-\$ 15.00$

Supplement includes additions and changes to the Rules from March 20, 1967-July 1, 1969. 


\section{ID} MICROFILM READER

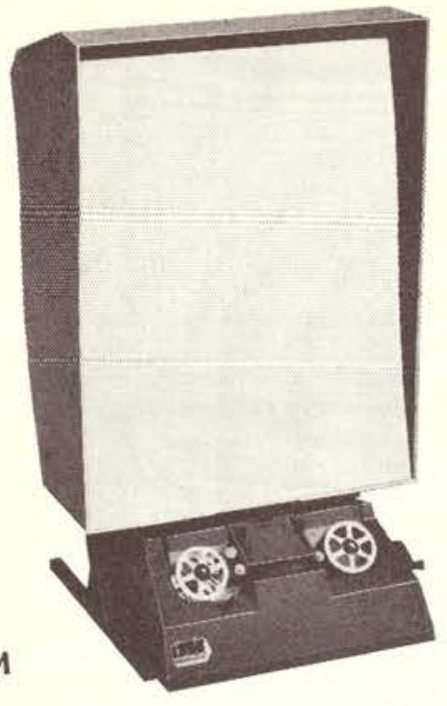

Projects easy-to-read images on an extra large (24x24 inch) screen. Handles $16 \mathrm{~mm}$ or $35 \mathrm{~mm}$ microfilms reel to reel or cartridge to reel.

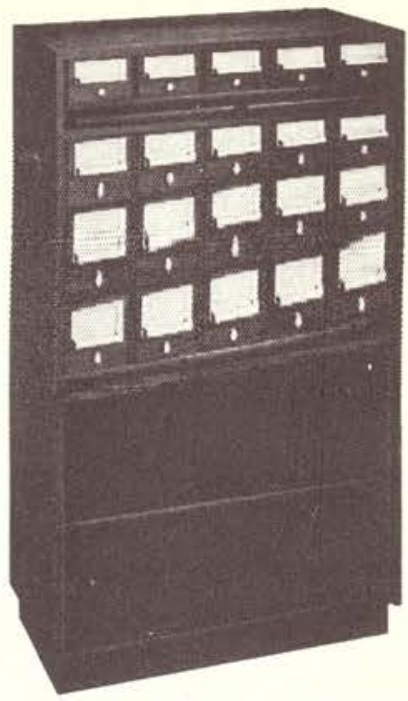

CARD

CATALOG

CABINETS

Five, 10 and 15 plastic tray sectional units. Modern "hooded" construction. Walnut or Teak vinyl laminate finish. Bookcase or metal bases.
Gets magazines off the shelves ... out where they are easier to see. Stores and displays as many as 200 issues in $8 \mathrm{sq}$. ft. of floor space.

\section{SERIES 8000 PERIODICAL DISPLAYER}

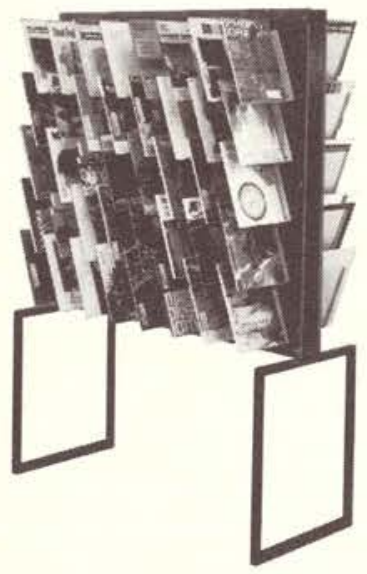

Modern wood, metal and acrylic construction. Each revolving module holds at least 24 magazines. One to four modules. Also with storage base.

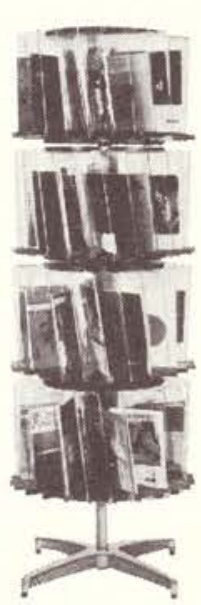

MAR-LINE PERIODICAL DISPLAYERS

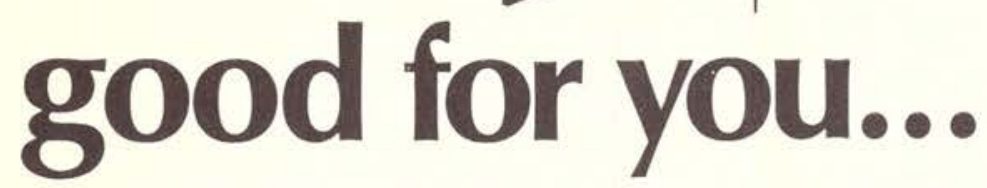

Keeping up to date on new developments in the library field is a full-time job. We try to help you by separating the genuine advances from the merely novel. Here are four new products we believe to be worthy of your consideration. Please write for illustrated brochures.

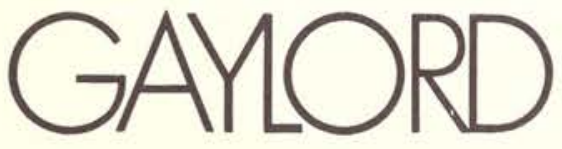

where new things are happening 